\title{
The impact of residential growth patterns on vehicle travel and pollutant emissions
}

\author{
Deb Niemeier \\ University of California, Davis ${ }^{\text {a }}$
}

\author{
Song Bai \\ University of California, Davis ${ }^{b}$
}

\author{
Susan Handy \\ University of California, Davis ${ }^{c}$
}

\begin{abstract}
In light of the increasing reliance on compact growth as a fundamental strategy for reducing vehicle emissions, it is important to better understand how land use-transportation interactions influence the production of mobile source emissions. To date, research findings have produced mixed conclusions as to whether compact development as a strategy for accommodating urban growth significantly reduces vehicle travel and, by extension, mitigates environmental impacts, particularly in the area of air quality. Using an integrated simulation approach coupled with long-term land development scenarios, we conducted an assessment of the impacts of different long-term primarily residential growth patterns on vehicle travel and pollutant emissions in the eight counties of the San Joaquin Valley region in central California. The results suggest that higher residential densities result in slightly decreased regional vehicle travel and emissions. Our comparative analysis also suggests that the effects of future land use growth patterns may vary among different spatial areas. That is, compact growth strategies can result in significantly more travel and emissions changes in already fairly urbanized counties. This work indicates a minimum density threshold of approximately 1500 households per square mile is necessary to achieve commensurate emissions reductions relative to existing densities.
\end{abstract}

Keywords: Planning; Residential density; VMT; Air quality

\section{Introduction}

Linking land use, transportation, and air quality has become an increasingly critical need in contemporary urban planning. In particular, a better understanding of the effects on travel activity and vehicle emissions of land use strategies and growth management policies that prioritize compact development is critical for facilitating effective long-term planning decisions. However, the land use-transportation interaction is complicated. To date, research has produced mixed conclusions as to whether compact development as a strategy for accommodating urban growth significantly reduces vehicle travel (e.g. Badoe and Miller 2000) and, by extension, mitigates environmental impacts, particularly in the area of air quality. For example, some studies have found that higher residential densities are typically associated with lower regional per capita travel (Ewing and Cervero 2001; Ewing et al. 2002; Golob and Brownstone 2005), shorter trip length (Cervero 1996), lower vehicle trip rates (Cervero and Kockelman 1997; Ewing and Cervero 2001), and higher non-auto mode splits (Dun-

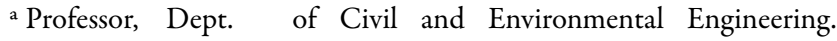
dniemeier@ucdavis.edu.

b Postdoctoral scholar, Dept. of Civil and Environmental Engineering.

c Professor, Dept. of Environmental Science and Policy.
}

phy and Fisher 1996; Ewing et al. 2002). Other studies have suggested that the relationship between density and travel activity is unclear, or that there are no direct effects (e.g. Kockelman 1997; Miller and Ibrahim 1998; Pickrell 1999).

Extending our understanding of how changes in land use and VMT affect air quality is also problematic because the relationship between air quality effects and vehicle travel is nonlinear. There is some evidence that emissions per household for criteria pollutants, those air pollutants regulated by the U.S. Environmental Protection Agency, are slightly negatively correlated with household density (Frank et al. 2000), in particular when smart growth in redevelopment and infill areas is compared to imbalanced or dispersed growth (Liu 2003). A recent review of scenario-based long-term planning exercises from more than 50 different metropolitan areas indicated a median reduction of roughly two percent in vehicle miles traveled and nitrous oxides emitted had resulted from an 11 percent increase in density over trend conditions (Bartholomew 2007). These findings are not out of range with those produced from another study using travel forecasting and scenarios, which found a reduction of approximately five to six percent in vehicle emissions as a result of an approximately 10 percent increase in population density (Stone et al. 2007). 
One of the major problems in connecting changes in land use and vehicle travel to air quality impacts is that it is usually difficult to translate changes in one or the other directly into vehicle emissions reductions (Louis Berger Group 2004). Handy (1996) noted that the methods used to study the relationships between land use and transportation have traditionally fallen into two categories: empirical studies and studies relying on travel forecasting simulation methods. One limitation of the empirical land use-transportation studies, regardless of whether the approach is aggregate or disaggregate, is that the mobile source estimation is delinked from any actual (or simulated) travel conditions or network, and must usually be derived using averages. The emissions-speed curves for most pollutants are generally parabolic and therefore changes in speed can create significant changes in emissions. Conversely, studies based on simulation have an advantage in that travel speeds can be attached to an actual network, although traditional travel demand models are not always well-linked to relevant policy questions. The simulation approaches, though dependent on the quality of the models used, offer the potential to explore the effects of development pattern scenarios as a way of examining alternative futures.

In this study, we use an integrated modeling framework to examine future mobile-source air pollutant emissions under a variety of long-term growth scenarios in the San Joaquin Valley (SJV) in central California. The San Joaquin Valley currently experiences severe air pollution problems, with all the concomitant emissions control challenges associated with population expansion, which has in turn driven changes in transportation, industry, agriculture, and power generation (Hall et al. 2006). Over the next 30 years, the population of California is expected to grow by 15 million, with roughly 25 percent of that growth occurring in the SJV (California Department of Finance 2007). Where this growth goes and how it is placed within the context of the cityscape are vitally important to achieving many of the state's environmental goals, including reducing air quality problems and changing the long-term anthropogenic drivers of global warming.

\section{Empirical setting}

Our study takes place in the heart of the SJV and includes eight counties: Fresno, Kern, Kings, Madera, Merced, San Joaquin, Stanislaus, and Tulare. Each county has its own federally designated metropolitan planning organization and operates its own four-step travel model. The counties are part of the San Joaquin Valley Air Pollution Control District. The region is designated by the U.S. Environmental Protec- tion Agency (EPA) as an "extreme" nonattainment area for national one-hour ozone standard and "serious" for national eight-hour ozone standard (U.S. Environmental Protection Agency 2004), The most recent conformity demonstration was conducted in 2007. Each of the SJV counties has longterm growth projections that are significant in terms of the potential impacts to county travel and land use (Table 1; Figure 2).

Historically (Figure 1), the populations of the counties have grown at an average rate of about three percent per year (Pop), with VMT growth exceeding that rate. Average density across all of the counties has remained fairly flat regardless of population growth. The estimated transportation greenhouse gas (GHG) emissions (F) have also increased as population has increased and are projected to roughly approximate increases in VMT as new regulations come into play (e.g., the Pavley standards, which regulate GHG emissions in new vehicles, and the Low Carbon Fuel Standard). Official state projections indicate that San Joaquin County will experience the highest growth in population, adding more than 660000 people between 2000 and 2030, while Fresno County is projected to have the largest residential and employment growth, adding more than 200000 new households and 270000 employees by year 2030 .

To assess the impact of potential long-term growth patterns within the eight county region, we developed a process that included looking at a variety of regional and local policy variables to define a number of different long-term growth scenarios, all physically plausible but some more politically realistic than others. The variables and the scenarios were vetted by an expert review committee and then used to simulate four different land-use-change scenarios using UPlan (Johnston et al. 2003). The outputs of UPlan were then used to derive inputs to each of the eight counties' travel demand models.

\subsection{Regional and local policy variables}

Combinations of regional and local policy variables ( $\mathrm{Ta}-$ ble 2) were evaluated to establish working scenarios for testing the travel implications of different long-term growth patterns. Regional variables represent policy issues that the state largely influences, with local participation generally funneled through regional bodies (e.g., the pollution control board or the metropolitan planning organizations). Local policy variables are assumed to be mostly or predominantly influenced by local cities and to a lesser degree by the county. To establish our working scenarios, we reviewed current local and regional policy documents with respect to each of the major variables. 


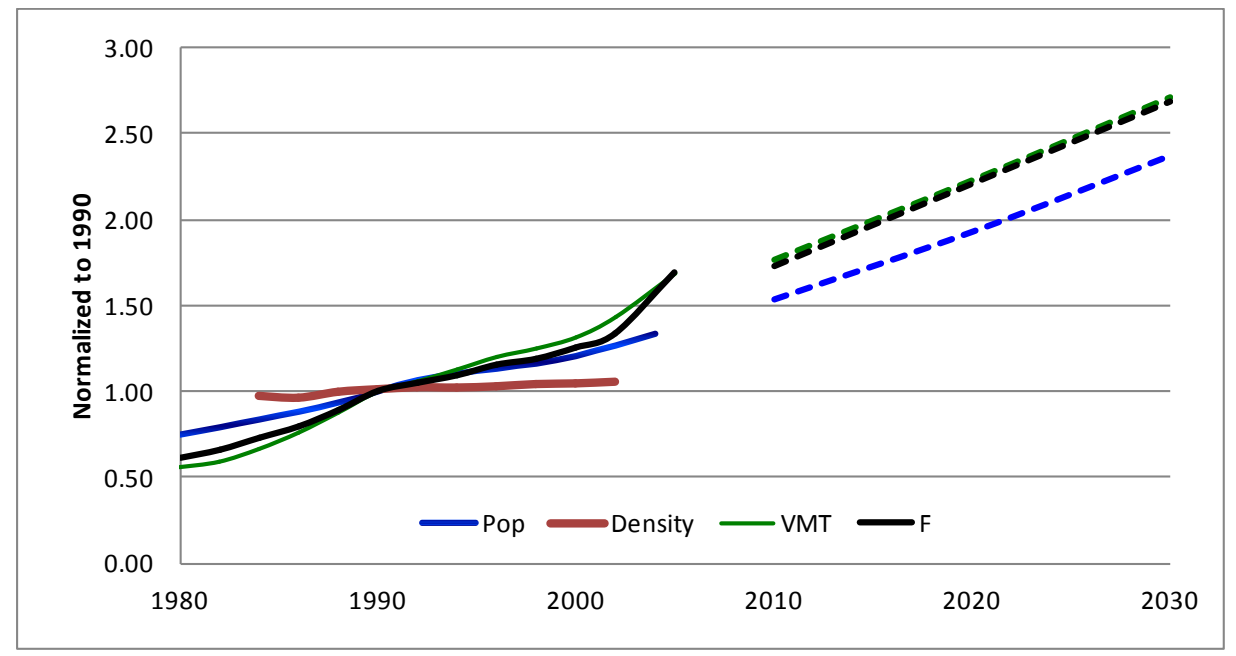

Figure 1: Historical growth patterns in population (Pop), density, VMT, and Transport GHGs (F).

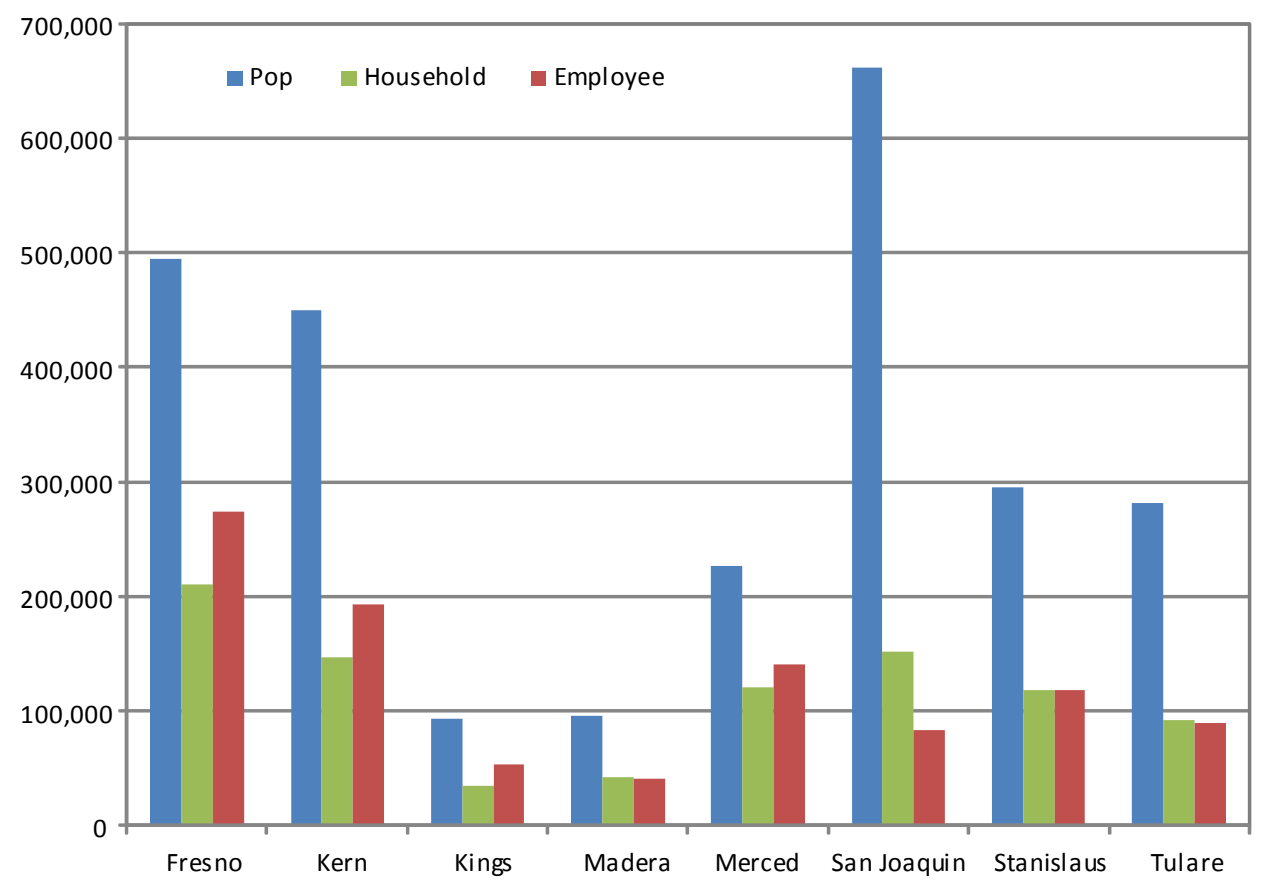

Figure 2: Projected growth in population, number of households, and employment, SJV counties, 2000-2030. 
Table 1: County population, household and employment growth projections.

\begin{tabular}{lrrrrrrr}
\hline \multirow{2}{*}{ County } & \multicolumn{3}{c}{ Year 2000 } & & \multicolumn{3}{c}{ Year 2030 } \\
\cline { 2 - 3 } & Pop & \multicolumn{1}{c}{ HH } & \multicolumn{1}{c}{ Emp } & & Pop & HH & \multicolumn{1}{c}{ Emp } \\
\hline Fresno & 803401 & 271620 & 335168 & & 1297476 & 481618 & 609393 \\
Kern & 664694 & 213289 & 247389 & & 1114878 & 360392 & 439926 \\
Kings & 129823 & 37957 & 47228 & & 223767 & 73036 & 101033 \\
Madera & 124372 & 36979 & 35506 & & 219832 & 78915 & 76254 \\
Merced & 210876 & 104871 & 83547 & & 437880 & 225189 & 223734 \\
San Joaquin & 567798 & 205597 & 200621 & & 1229757 & 357973 & 284017 \\
Stanislaus & 449777 & 146057 & 175149 & & 744599 & 263789 & 293938 \\
Tulare & 369355 & 112608 & 132445 & 650466 & 204391 & 222215 \\
\hline
\end{tabular}

Source: Individual travel demands from each county.

Table 2: Variables potentially affecting long-term growth patterns in the SJV.

\begin{tabular}{ll}
\hline Regional Policy Variables & Local Policy Variables \\
\hline - Transportation investments: & - Transportation investments: \\
- major highways & - Local roads \\
- rail & - Local zoning policies \\
- bus & - Urban service boundaries \\
- air & - Transit oriented development \\
- High-speed rail & \\
- Agricultural preservation & \\
- Habitat preservation & \\
\hline
\end{tabular}

We used the Regional Transportation Plans (RTPs) to determine policy goals and trends for transportation infrastructure development. In reviewing these plans, we noted that a consistent theme was to promote mobility while preserving the environment. Most counties were planning to upgrade highway systems and complete gaps between local and state highway systems. And many plans also emphasized promoting alternatives to automobile travel including inter-city rail and bus service, intra-city public transportation, and bicycle and pedestrian facilities. The circulation elements in city and county general plans were used to determine policies for local road, rail, and bus development. The city and county general plans were also used to determine future land use policies, including zoning designations, density limits, and urban service boundaries. These policies shape what kind of land development will happen where.

We selected a limited number of combinations of values for each policy variable based on four distinct policy scenarios (Table 3). The Baseline Growth (BG) scenario assumes no change in the trend for all variables. The Controlled Growth (CG) scenario assumes no roadway capacity enhancements and, conversely, expansion of alternative forms of transportation and increases in residential densities through infill development and changes in zoning density limits. The Uncontrolled Growth (UG) scenario assumes low and very low residential densities and significant roadway capacity expansion with little or no implementation of alternative forms of transportation. The As Planned (AP) scenario represents current plans; in this scenario, there are both new roads and high speed rail, and densities vary between low and high. We assembled a panel of seven experts with diverse backgrounds in economics and land use, transportation, air quality, agriculture, and energy policy to review key variables underpinning the policy scenarios. The expert panel included members representing the California Energy Commission, the California High Speed Rail Authority, the California Air Resources Board, Caltrans, the Great Valley Center (a regional NGO), and academic experts on economics and air quality. 
Table 3: Summary of future growth pattern scenarios.

\begin{tabular}{|c|c|c|c|c|}
\hline & $\begin{array}{c}\text { Scenario 1: } \\
\text { Baseline (BG) }\end{array}$ & $\begin{array}{c}\text { Scenario 2: } \\
\text { Controlled (CG) }\end{array}$ & $\begin{array}{c}\text { Scenario 3: } \\
\text { Uncontrolled (UG) }\end{array}$ & $\begin{array}{c}\text { Scenario 4: } \\
\text { As-Planned (AP) }\end{array}$ \\
\hline Transportation & No change & $\begin{array}{l}\text { - No new roads } \\
\text { - High-speed rail }\end{array}$ & $\begin{array}{l}\text { - New roads } \\
\text { - Road capacity } \\
\text { expansion as } \\
\text { planned } \\
\text { - No high-speed rail }\end{array}$ & $\begin{array}{l}\text { - New roads } \\
\text { - Road capacity } \\
\text { expansion as } \\
\text { planned } \\
\text { - High-speed rail }\end{array}$ \\
\hline Land use & $\begin{array}{l}\text { Growth follows } \\
\text { existing patterns }\end{array}$ & $\begin{array}{l}\text { - High-density } \\
\text { residential } \\
\text { - Transit oriented } \\
\text { development } \\
\text { - Infill and } \\
\text { redevelopment }\end{array}$ & $\begin{array}{l}\text { Low- and } \\
\text { very-low-density } \\
\text { residential }\end{array}$ & $\begin{array}{l}\text { - Residential } \\
\text { densities as } \\
\text { planned } \\
\text { - Some increased } \\
\text { preservation }\end{array}$ \\
\hline
\end{tabular}

\subsection{Land use modeling}

We selected UPlan, a heuristic GIS-based program for building land-use scenarios developed at UC Davis (Johnston et al. 2003) to translate the policy variables into long-term growth patterns. In UPlan, each land use variable translates into three possible inputs: attraction factors, discouragement factors, or masking factors (Figure 3). For example, high speed rail stations and highway networks act as attraction factors for growth (i.e., UPlan assumes population growth will expand in these areas before moving into other areas). Conversely, the agricultural and habitat preservation areas act as discouragement factors for growth. We used current trends to estimate growth in agricultural preservation agreements and land that will remain undeveloped. For habitat restoration, we assumed that land currently under contract will remain undeveloped and used existing trends to project any growth in habitat preservation. Land identified as being preserved was assigned discouragement factors for development in the UPlan model. Finally, transportation facilities were given no-development buffers consistent with the fixed assumptions recommended by the expert panel. UPlan has a 50-meter grid cell resolution.

A GIS layer was developed for all of the relevant input variables for each scenario and a quality assurance check was completed to ensure that results were reasonable. We allocated 100 percent of projected population growth for all scenarios and used input levels as defined in Table 4; all inputs are the same across the four scenarios except as noted.

The UPlan modules created projections of population and employment for specified grid cell sizes, based on attraction, discouragement, and masking factors, and then produced the number of households for four residential density categories and the number of employees for three employment categories (Table 5) as its final result. The CG and UG scenarios bracket growth patterns between high density (compact growth conditions) and low density (sprawl-like conditions). UPlan grid cell results were aggregated into each county's traffic analysis zones (TAZs) as inputs for travel demand modeling.

\subsection{Travel modeling}

In order to use UPlan results, it was necessary to perform two additional steps to convert the results for use in the travel models. First, because UPlan forecasts only the new growth (or changes) in the assigned household and employment numbers between the base year and the target year (2030), we combined county-specific base year land-use data with UPlan outputs to generate 2030 household and employment numbers by TAZ. Second, because UPlan provides a limited number of household and employment categories and these categories tend to be more aggregate than the resolution of the data used in the travel models, we used the county socio-demographic data represented in the base year travel demand modeling to sub-divide UPlan categories into detailed household or employment categories (e.g., single-family and multi-family households; manufacturing, retail, and government employment, etc).

As noted previously, each county has its own four-step travel model. We utilized these models, including trip generation, trip distribution, mode split, and trip assignment, with 


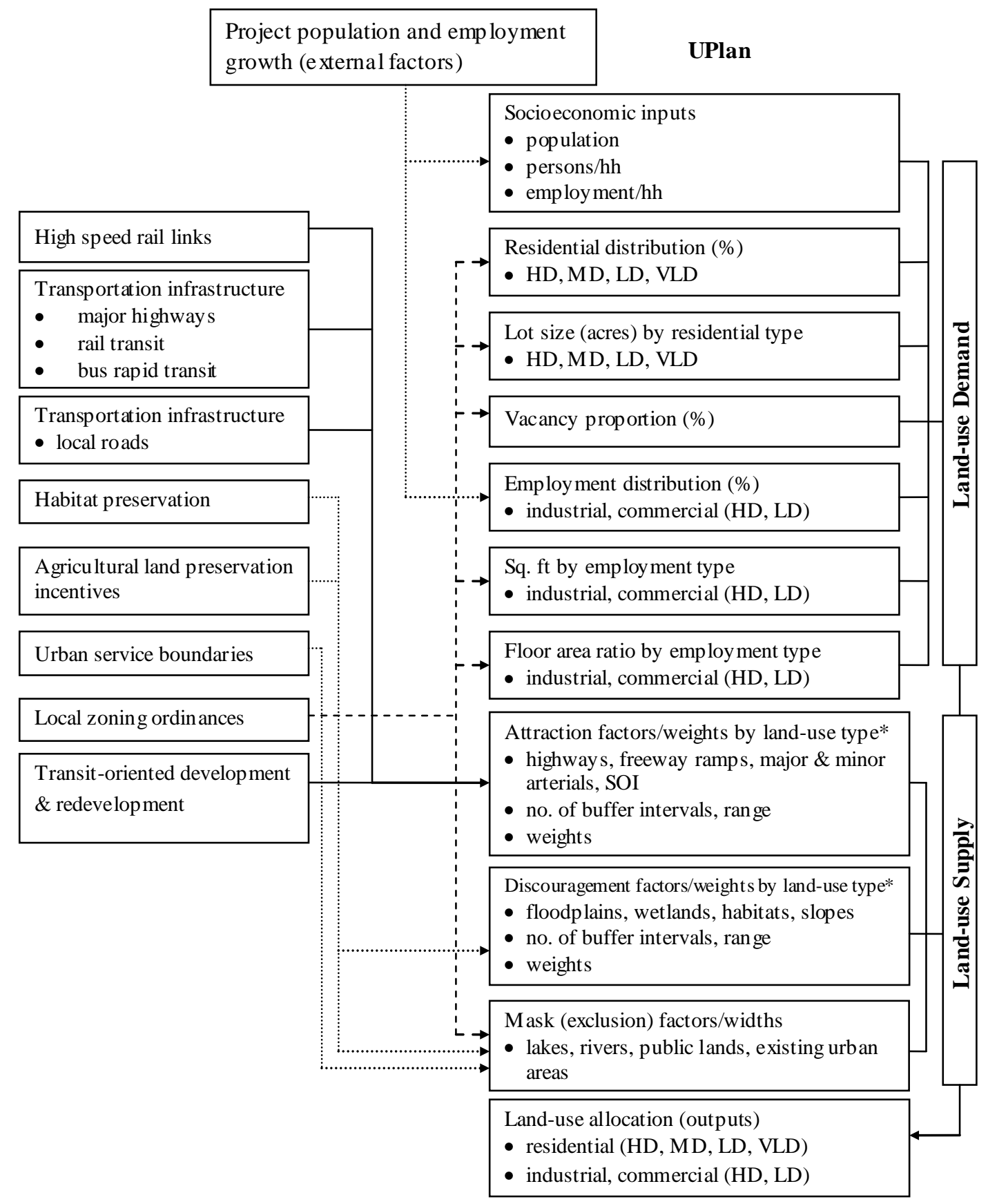

* The very low density (VLD) residential category is not included.

HD: High Density, MD: Medium Density, LD: Low Density, VLD: Very Low Density

Figure 3: Translation of variables into UPlan inputs. 
Table 4: Assumptions for translation of variables into land use model inputs.

\begin{tabular}{|c|c|c|c|c|}
\hline & $\begin{array}{c}\text { Scenario 1: } \\
\text { Baseline (BG) }\end{array}$ & $\begin{array}{c}\text { Scenario 2: } \\
\text { Controlled (CG) }\end{array}$ & $\begin{array}{c}\text { Scenario 3: } \\
\text { Uncontrolled (UG) }\end{array}$ & $\begin{array}{c}\text { Scenario 4: } \\
\text { As-Planned (AP) }\end{array}$ \\
\hline General plans: & Legacy general plan & County general plan & Legacy general plan & County general plan \\
\hline \multirow[t]{2}{*}{ Attractions: } & 1998 freeway ramps & 1998 freeway ramps & 2030 freeway ramps & 2030 freeway ramps \\
\hline & $\begin{array}{c}1998 \text { network } \\
\text { Existing urban } 1000 \mathrm{ft} \\
\text { buffer } \\
\text { N/A }\end{array}$ & $\begin{array}{c}1998 \text { network } \\
\text { Existing urban } 500 \mathrm{ft} \\
\text { buffer } \\
\text { HSR station }\end{array}$ & $\begin{array}{c}2030 \text { network } \\
\text { N/A } \\
\text { N/A }\end{array}$ & $\begin{array}{c}2030 \text { network } \\
\text { Existing urban } 1000 \mathrm{ft} \\
\text { buffer } \\
\text { HSR station }\end{array}$ \\
\hline Redevelopment: & $\mathrm{N} / \mathrm{A}$ & Allowed & $\mathrm{N} / \mathrm{A}$ & $\mathrm{N} / \mathrm{A}$ \\
\hline \multirow[t]{7}{*}{ Masks: } & Existing urban & $\begin{array}{l}\text { Existing urban minus } \\
\text { redevelopment areas }\end{array}$ & Existing urban & Existing urban \\
\hline & Lakes & Lakes & Lakes & Lakes \\
\hline & Streams & Streams & Streams & Streams \\
\hline & Public lands & Public lands & Public lands & Public lands \\
\hline & HSR line $500 \mathrm{ft}$ buffer & HSR line $500 \mathrm{ft}$ buffer & HSR line $500 \mathrm{ft}$ buffer & HSR line $500 \mathrm{ft}$ buffer \\
\hline & Wetlands & Wetlands $50 \%$ increase & Wetlands & Wetlands $25 \%$ increase \\
\hline & Floodplains & $\begin{array}{c}\text { Floodplains 50\% } \\
\text { increase }\end{array}$ & Floodplains & $\begin{array}{c}\text { Floodplains } 25 \% \\
\text { increase }\end{array}$ \\
\hline Residential growth: & Trend, four types & One type, $100 \% \mathrm{HD}$ & $\begin{array}{c}\text { Two types, } 50 \% \text { RL and } \\
50 \% \text { RVL }\end{array}$ & Trend, four types \\
\hline Employment growth: & Trend, three types & Trend, three types & Trend, three types & Trend, three types \\
\hline
\end{tabular}

Note: HD: High Density, RL: Residential - Low Density, RVL: Residential - Very Low Density; HSR: High Speed Rail.

the land use patterns obtained from UPlan defined for each model's TAZs (numbers of households and employees by different categories). It is also important to note that, for the scenarios in which high speed rail is included, some additional adjustments were made. Based on forecasts provided by the California High-Speed Rail Authority (CHSRA), seven percent of private auto travelers will be diverted to the high-speed train (California High-Speed Rail Authority 2000). To spatially quantify the effects of high-speed rail in the Controlled Growth and As Planned scenarios, we first identified the highway corridors used by through-county traffic, the county highway network gateways, and the associated external-external trips in the origin-destination (OD) matrix. We then identified the traffic analysis zones in the downtown areas that were potentially affected by high-speed rail stations and the associated external-internal trips in the OD matrix. We reduced the identified external-external and external-internal trips by seven percent before loading the OD matrix into trip assignment models, and we increased the corresponding number of internal-internal trips associated with those identified downtown area traffic analysis zones in trip assignment.

\subsection{Emissions modeling}

In the final step, we used the UCDrive model to combine travel modeling results with MOBILE6 (a model for predicting on-road mobile source pollutant emissions) emission factors to generate SJV mobile source emissions. UCDrive is a grid-based mobile source inventory model, which has the ability to simulate fine-scale vehicle emissions resulting from travel activity changes (Niemeier and Zheng 2004; Niemeier et al. 2004). Specifically, travel modeling results were organized by roadway link (e.g., link VMT and speed) and by TAZ (e.g., number of vehicle starts and within-zone VMT). Emissions rates from MOBILE6 were divided into two categories: link emissions (e.g., running exhaust and running loss) and non-link emissions (e.g., start exhaust and hot soak). These MOBILE6 emission rates were also revised based on SJV county-specific information such as temperature and relative humidity profiles, fuel program and inspection/maintenance program, and then aggregated into composite emission factors across vehicle type and vehicle age.

The UCDrive modeling process calculates three types of emissions rates: interzonal running emissions, intrazonal 
Table 5: Number of SJV new households and employment allocated by UPlan.

\begin{tabular}{lcccc}
\hline & $\begin{array}{c}\text { Scenario 1: } \\
\text { Baseline (BG) }\end{array}$ & $\begin{array}{c}\text { Scenario 2: } \\
\text { Controlled (CG) }\end{array}$ & $\begin{array}{c}\text { Scenario 3: } \\
\text { Uncontrolled (UG) }\end{array}$ & $\begin{array}{c}\text { Scenario 4: } \\
\text { As-Planned (AP) }\end{array}$ \\
\hline $\begin{array}{l}\text { Residential Density: } \\
\text { High (20 DU/acre) }\end{array}$ & 189080 & 914860 & & 198020 \\
Medium (5 DU/acre) & 693326 & 37 & 29 & 702413 \\
Low (0.25 DU/acre) & 16997 & 0 & 895583 & 8802 \\
Very low (0.05 DU/acre) & 14889 & 220 & 18096 & 5124 \\
\hline Employment: & & & & 128347 \\
Industrial & 135032 & 128475 & 128428 & 292096 \\
High-density commercial & 296508 & 295916 & 291105 & 566991 \\
Low-density commercial & 589684 & 566220 & 566936 & \\
\hline
\end{tabular}

a Average household density expressed as dwelling units per acre (DU/acre), used in UPlan as a criterion to allocate new households from year 2000 to year 2030 .

running/trip-end emissions and interzonal trip-end emissions (Figure 4). Specifically, interzonal running emissions are estimated on a link-by-link basis by first identifying the composite emission factors (CEF) based on link speed. The total link emissions are then calculated by combining link activities with link-specific CEF. Finally, link emissions are distributed spatially (to grid cells) and temporally (to each hour of the day). The intrazonal running/trip-end and interzonal trip-end modules produce non-link emissions for each TAZ, based on trip productions, trip attractions and within-zone vehicle miles traveled. For each growth scenario, the results of the grid cell emissions for four tailpipe and evaporative pollutants, total organic gas (TOG, a typical form measured for mobile source hydrocarbon), carbon monoxide (CO), nitrogen oxides (NOx) and particulate matter (PM10), were aggregated into the regional total inventory for each SJV county.

\section{Results}

We conducted a comparative analysis of the travel and vehicle emissions results from the four planning scenarios at the regional level as well as at the county level. As noted earlier, residential density is a primary factor reflecting land use patterns in different growth scenarios. For the eight SJV eight counties, household density from the year 2000 and the density criteria applied in UPlan to allocate new households (see Table 5) were used to generate weighted average household densities corresponding to each growth scenario for the year 2030 (Table 6). We used these to analyze the association between density and the estimated changes in travel and emissions presented in the subsequent sections.

\subsection{Regional-level comparison}

At the regional level, the modeling results show consistent patterns across growth scenarios (Table 7): compared to the BG scenario, higher-density land use patterns in the CG scenario (with average densities between 6000 and 8000 households per square mile) tend to result in lower vehicle miles traveled (VMT) and vehicle hours traveled (VHT) at the regional level, as well as shorter travel distances at the trip level; conversely, significant increases in VMT, VHT, and average trip length are associated with low-density development in the UG scenario. As expected at the regional level, emissions of criteria and primary pollutants are correlated with vehicle miles traveled. Regional total emissions in the CG and UG scenarios reflect the low and high ends of the range of changes across the different scenarios-six to 10 percent lower and seven to 10 percent higher, respectively, than under the BG scenario.

\subsection{County-level comparison}

At the county level, differences across growth scenarios suggest a similar pattern. The CG and UG scenarios tend to bracket the lowest and highest estimates of traffic activities by 2030 . However, the magnitude of changes relative to the BG scenarios varies by county (Figure 5). Compared to the baseline growth pattern, high-density growth scenarios result in VMT reductions of roughly 10 percent in Fresno and San Joaquin Counties, two areas with large urban centers (the cities of Fresno and Stockton, respectively); however, VMT reductions are less than five percent in predominantly rural Kings and Madera Counties. In contrast, uncontrolled growth with low densities in Merced and Stanislaus Counties 


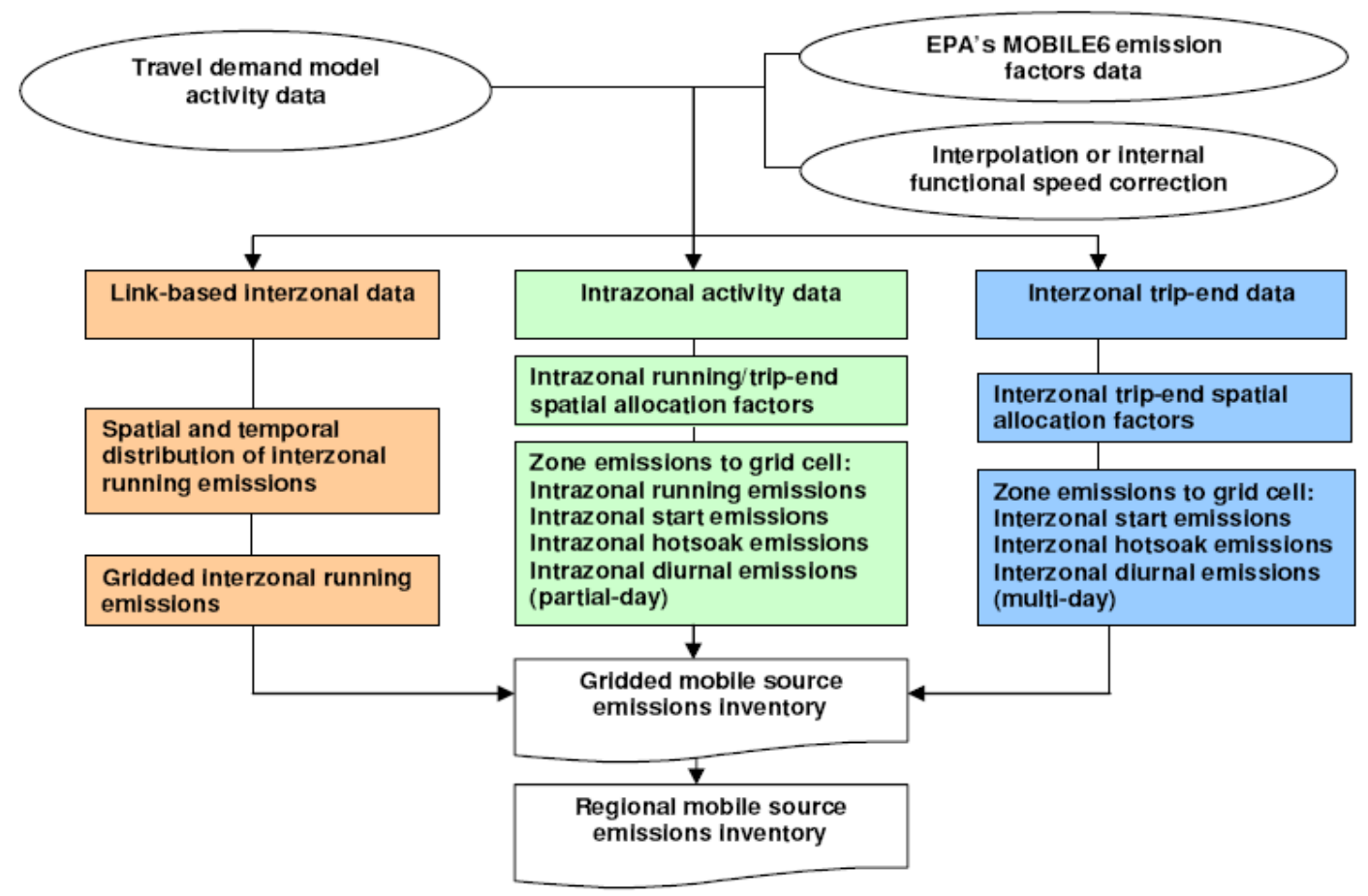

Figure 4: Mobile source emissions modeling process in UCDrive.

is associated with approximately 30 percent higher VMT than would be expected under the baseline growth condition.

To further investigate the relationship between densities and travel activities, we focused on the comparison between the CG and AP scenarios in each county. In particular, this comparison identifies the county-level changes in a compact growth (CG) pattern versus what would be expected under the "business-as-usual" scenario (AP). Residential densities in the CG scenarios are 90 to 150 percent higher (roughly 3000 to 4000 more households per square mile) than under the AP scenarios across all SJV counties (Figure 6). Except for Merced and Kern Counties, where VMT and VHT marginally increase, the modeling results for other counties indicate a consistent reduction in per-household vehicle miles and hours traveled in the CG scenarios. Compact growth patterns in San Joaquin and Stanislaus Counties result in the largest reductions in VMT and VHT, while traffic activities drop moderately in rural Kings and Madera Counties.

We calculated the elasticity of vehicular travel with respect to density in order to quantify the impact of compact growth in each of the SJV counties relative to the as-planned (AP) scenario. ${ }^{1}$ Specifically, elasticity in this context is calculated

\footnotetext{
${ }^{1}$ Care should be taken in reviewing elasticities given the large changes in densities.
}

as the ratio of the percentage change in household VMT or VHT to the associated percentage change in residential density. In six of the eight SJV counties, VMT and VHT elasticities are negative with respect to household density, ranging from -0.19 to -0.05 and from -0.27 to -0.01 , respectively (Table 8). Based on the elasticities, the compact growth pattern in San Joaquin County (with the largest population growth in the SJV region between 2000 and 2030) has the most significant impact on vehicular travel; given a 10 percent increase in residential density, reductions of 1.9 and 2.7 percent in VMT and VHT (respectively) can be reasonably anticipated. In terms of absolute values in travel activity, the San Joaquin County results also suggest an average decrease of 1519 household annual vehicle miles given every 1000 households per square mile increase in density. This result is slightly higher than that calculated for California as a whole in Golob and Brownstone (2005). The impact of compact growth appears marginal in Kings and Madera Counties, two areas in the SJV region with the smallest projected population increases by 2030. A 10 percent increase in residential density is associated with a reduction of only 0.5 percent in household VMT and VHT. Increases in Merced are associated with inter-county travel growth.

Finally, we examined the effects of the different growth patterns on vehicle emissions. It should be noted that, in addi- 


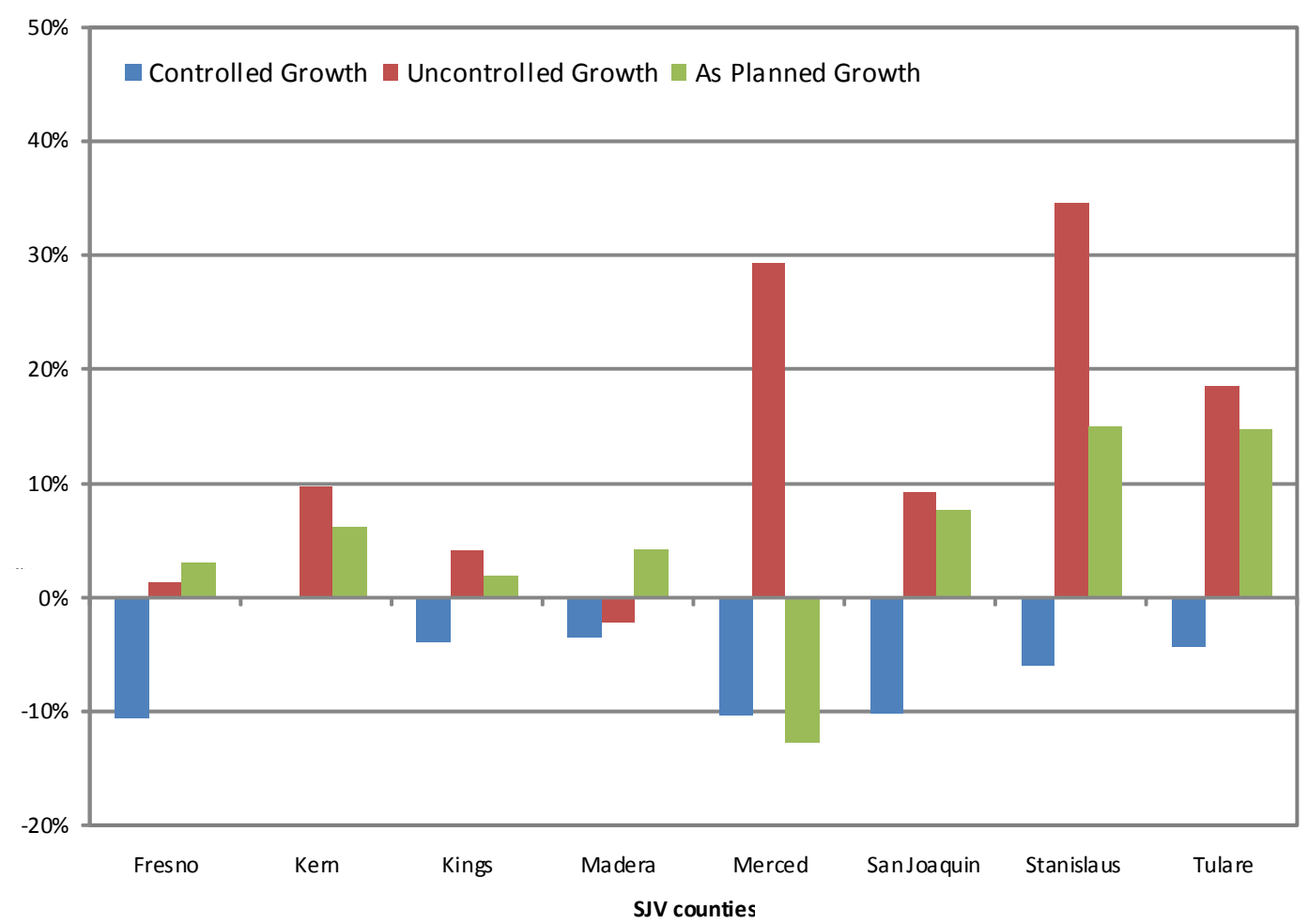

Figure 5: County-level VMT changes in CG, UG and AP scenarios by 2030 vs. BG scenario.

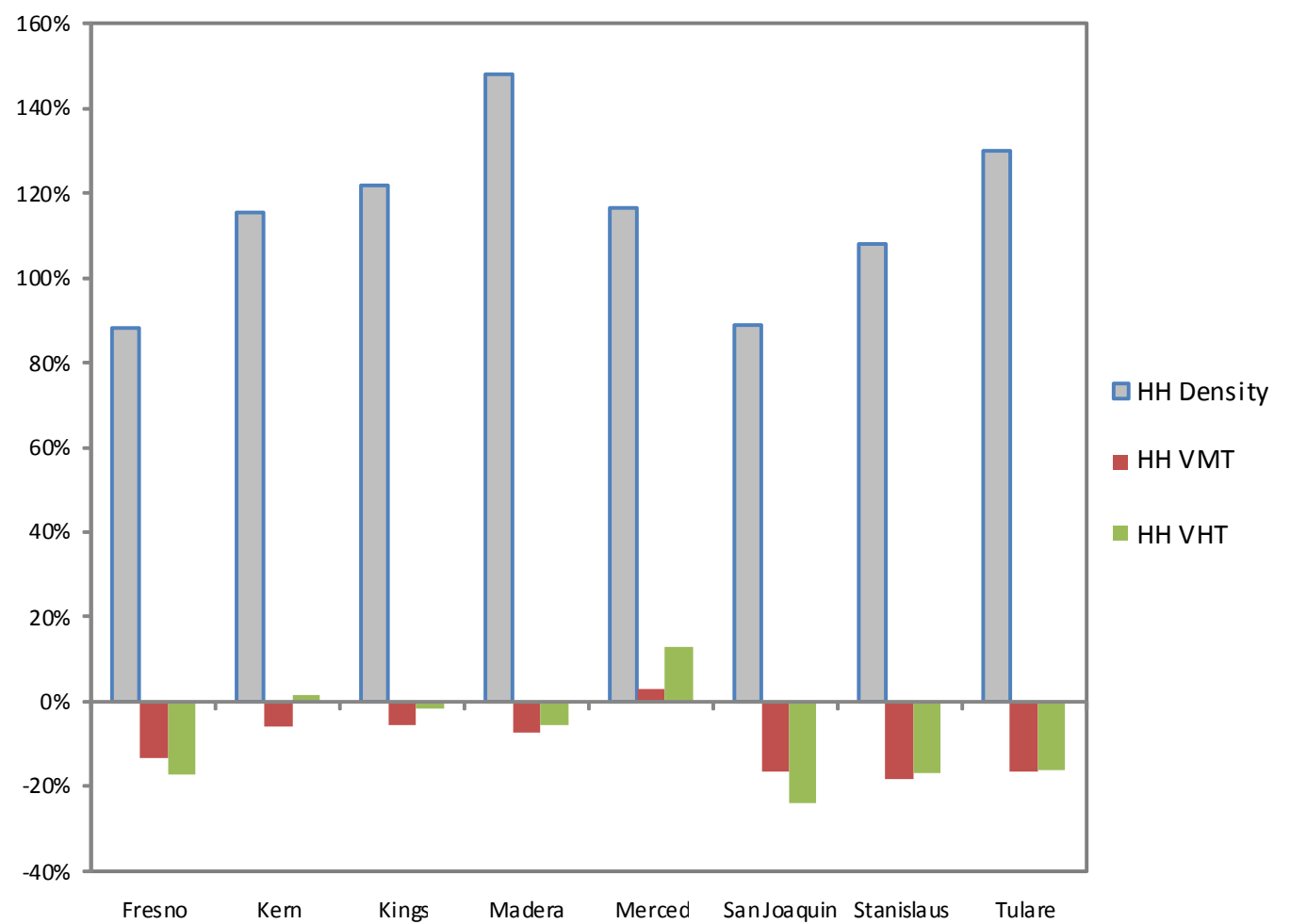

Figure 6: Household density and travel modeling results by county: Percentage difference in CG scenario by 2030 vs. AP scenario. 
Table 6: County household densities across growth scenarios.

\begin{tabular}{lccccc}
\hline County & $\begin{array}{c}\text { Year 2000 } \\
\text { Residential } \\
\text { Density }\end{array}$ & $\begin{array}{c}\text { Scenario 1: } \\
\text { Baseline (BG) }\end{array}$ & $\begin{array}{c}\text { Scenario 2: } \\
\text { Controlled (CG) }\end{array}$ & $\begin{array}{c}\text { Scenario 3: } \\
\text { Uncontrolled (UG) }\end{array}$ & $\begin{array}{c}\text { Scenario 4: } \\
\text { As-Planned (AP) }\end{array}$ \\
\hline Fresno & 1657 & 3448 & 6519 & 1003 & 3463 \\
Kern & 1276 & 2748 & 5996 & 818 & 2782 \\
Kings & 839 & 2744 & 6279 & 532 & 2833 \\
Madera & 1033 & 2779 & 7315 & 565 & 2950 \\
Merced & 2109 & 3573 & 7818 & 1068 & 3609 \\
San Joaquin & 1775 & 3284 & 6511 & 1082 & 3448 \\
Stanislaus & 1689 & 3094 & 6670 & 1006 & 3206 \\
Tulare & 1459 & 2781 & 6456 & 887 & 2809 \\
\hline
\end{tabular}

Table 7: Travel modeling results for the SJV regional total: travel activities and emissions per day by 2030 (change vs. BG scenario).

\begin{tabular}{lcccr}
\hline & $\begin{array}{c}\text { Scenario 1: } \\
\text { Baseline (BG) }\end{array}$ & $\begin{array}{c}\text { Scenario 2: } \\
\text { Controlled (CG) }\end{array}$ & $\begin{array}{c}\text { Scenario 3: } \\
\text { Uncontrolled (UG) }\end{array}$ & $\begin{array}{c}\text { Scenario 4: } \\
\text { As-Planned (AP) }\end{array}$ \\
\hline VMT (million miles) & $184.2-$ & $172.3(-6 \%)$ & $206.8(+12 \%)$ & $193.9(+5 \%)$ \\
VHT (million hours) & $6.1-$ & $5.4(-11 \%)$ & $6.6(+8 \%)$ & $6.0(-2 \%)$ \\
Trip length (miles/trip) & $11.1-$ & $10.7(-4 \%)$ & $12.4(+12 \%)$ & $11.6(+5 \%)$ \\
TOG (tons) & $44.5-$ & $40.2(-10 \%)$ & $47.7(+7 \%)$ & $43.9(-1 \%)$ \\
CO (tons) & $679.3-$ & $631.2(-7 \%)$ & $747.7(+10 \%)$ & $702.9(+3 \%)$ \\
NO (tons) & $53.7-$ & $49.8(-7 \%)$ & $59.1(+10 \%)$ & $55.7(+4 \%)$ \\
PM (tons) & $7.7-$ & $7.2(-6 \%)$ & $8.5(+10 \%)$ & 8.1 \\
\hline
\end{tabular}

tion to VMT, there are other confounding factors in different growth scenarios that may influence changes in vehicle emissions; that is, changes in growth patterns will also change link vehicle speeds and the number of starts. Our emissions comparison reflects the combined influence of these factors. However, since running-exhaust emissions dominate the mobile source inventories, county-level emissions differences should be expected to correlate strongly with VMT changes across growth scenarios. As illustrated in Figure 7, vehicle emissions changes relative to the baseline growth scenario suggest patterns similar to observed VMT changes. High residential densities in the CG scenario generally result in a reduction of roughly $10-15$ percent in criteria and primary pollutant emissions in Fresno and San Joaquin Counties, while urban sprawl conditions potentially lead to an increase of more than 30 percent in vehicle emissions over the baseline growth pattern. Elasticities of vehicle emissions with respect to residential densities (Table 9), based on the comparison between the CG and AP scenarios, indicate that the effects of compact growth on emissions will be similar in magnitude to the effects seen ear- lier on VMT. For example, given a 10 percent increase in average residential density in Fresno and San Joaquin Counties by 2030 , a reduction of approximately 1.5 to 1.9 percent in vehicle pollutant emissions can be reasonably anticipated.

\section{Discussion and conclusions}

Using a simulation approach coupled with long-term land development scenarios, we assessed the impacts of different longterm growth patterns on vehicle travel and pollutant emissions in the eight counties of the San Joaquin Valley region in central California. The results, based on an integrated modeling process, suggest that higher residential densities can contribute to development patterns that decrease regional vehicle travel and emissions. In contrast, inefficient dispersed growth patterns tend to result in longer travel distances and times which, in turn, worsen air quality.

Previous studies linking land use and travel have produced a range of results regarding the quantitative effects of density on vehicle travel. Ewing and Cervero (2001) reviewed a 
Table 8: Travel modeling results and elasticity by county: CG vs. AP scenarios.

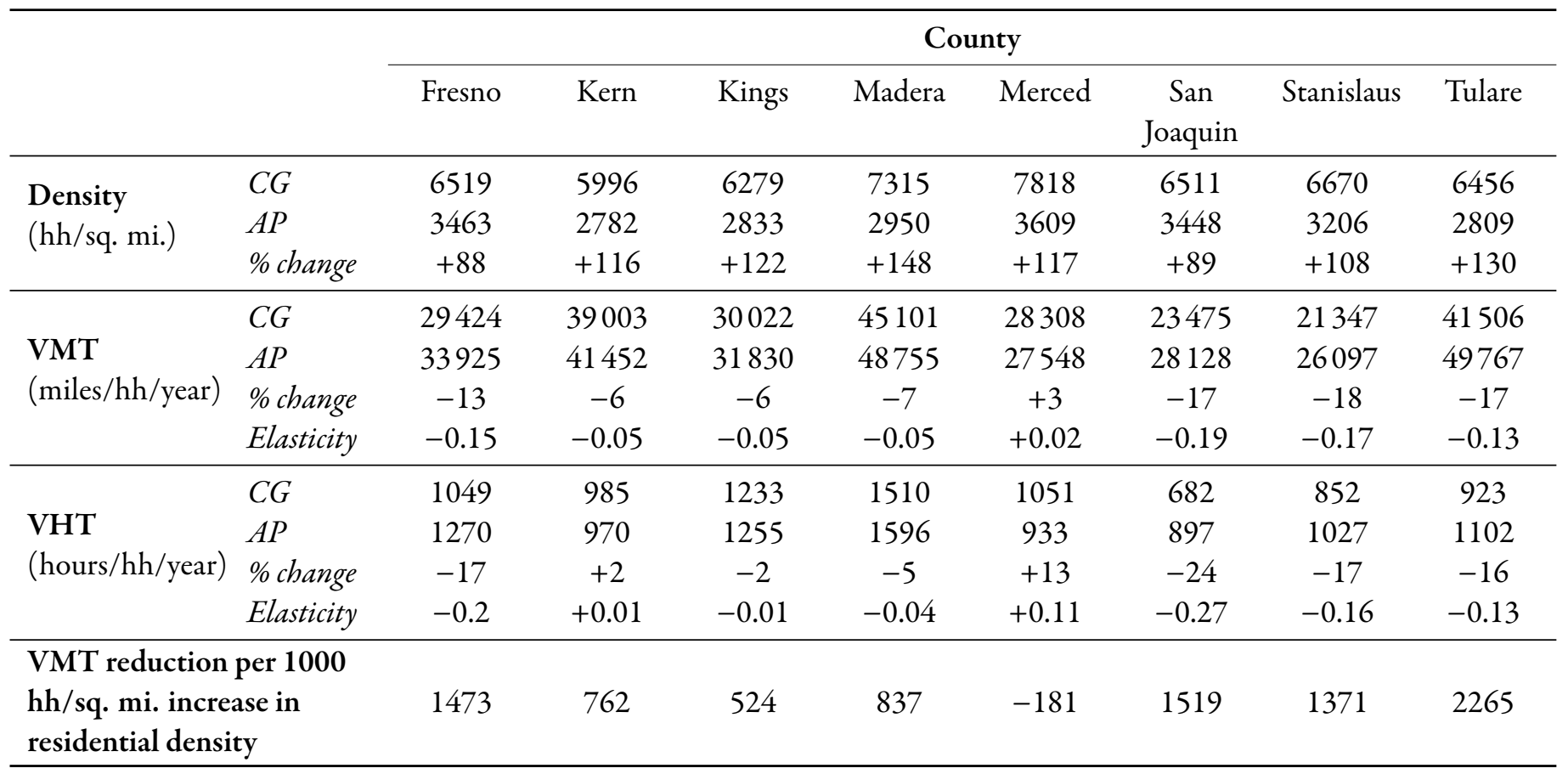

large group of empirical studies and calculated travel mileage elasticity values ranging from -0.16 to -0.05 . Golob and Brownstone (2005) found that households will drive 1171 miles per year less for every increase in housing density of 1,000 units per square mile, which is equivalent to a VMT elasticity of -0.12 with respect to residential density (assuming 30000 miles annual travel per household and 3000 households per square mile density as base, which is similar to the AP 2030 scenarios in our study). In a recently published report based on meta-analysis of regional simulation studies, the best estimate of the elasticity of VMT with respect to regional density was calculated as -0.075 (Ewing et al. 2007). In contrast, Stone et al. (2007) found the median vehicle travel (and emissions) elasticity to be -0.35 across eleven large metropolitan regions. Our study, however, indicates a median travel (VMT) elasticity of -0.09 with respect to residential density, which suggests that increased density has a much more moderate impact on travel reductions.

Our comparison analysis also suggests that the effects of future land-use growth patterns may vary among differently sized spatial areas (Figure 8). That is, the highest elasticities occur where land patterns are already densest, but the densest counties also experience the smallest changes in density, which is reasonable. Practically speaking, within the SJV region, compact growth strategies are likely to result in significantly more travel and emissions changes in counties that are already fairly urbanized. This finding is consistent with Stone et al. (2007), who also found that densification of urban areas was about 2.5 times more effective in reducing VMT than densifying rural areas. Our analysis also suggests that, specific to the SJV, we may have two categories of urban areas. Our work seems to indicate that a density threshold of approximately $1500 \mathrm{hh} / \mathrm{sq}$. mi. is necessary to achieving both VMT reductions and commensurate reductions in air pollutants relative to existing densities.

Since the integrated modeling process developed in this study is based on the traditional four-step travel demand model used by each county, travel activity effects are mainly measured with respect to roadway network performance, rather than travel behavior. Therefore, one important limitation of this study is the lack of consideration of some confounding factors, especially those at the local scale (e.g., availability of various travel modes, potential improvement of local transit, quality of the pedestrian environment, and people's perception of safety), which can play important roles in trip-making decisions and may directly influence travel and emissions in different growth scenarios. In addition, policies on residential density are primary drivers of the differences in development patterns in the scenarios, as the assumptions about employment density and commercial/industrial zoning do not vary between the scenarios (although employment location is influenced by other assumptions, such as the attrac- 


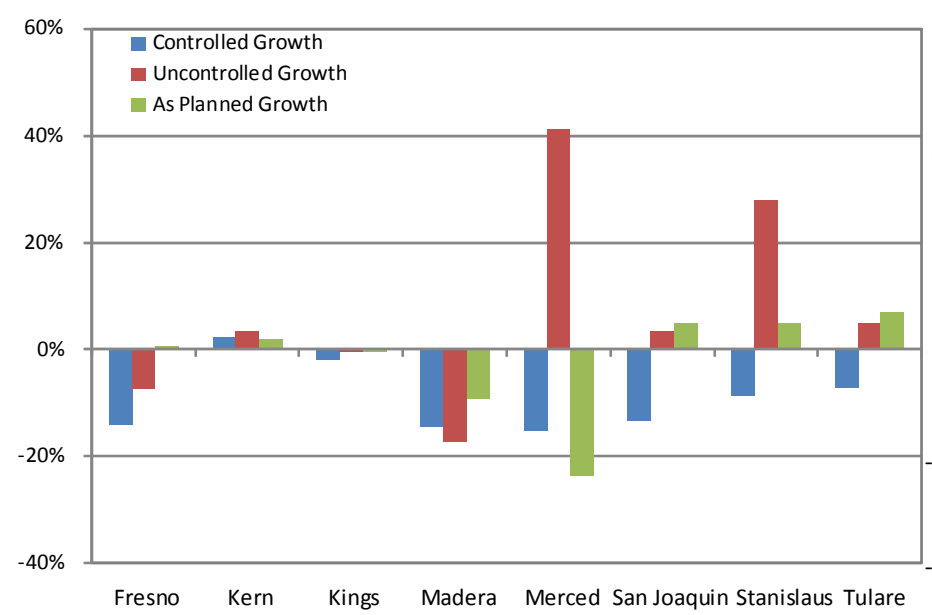

(a) TOG emissions

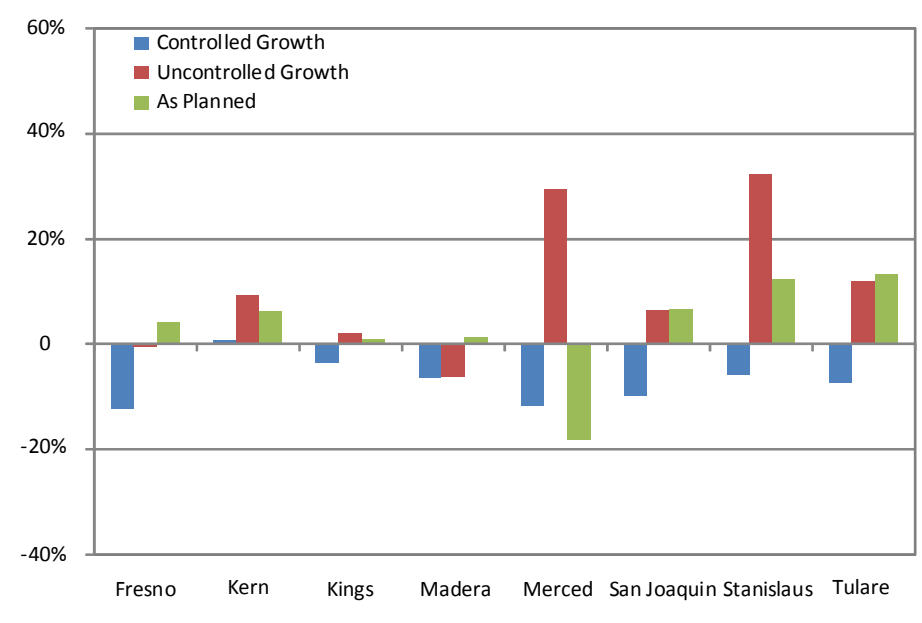

(c) NOx emissions

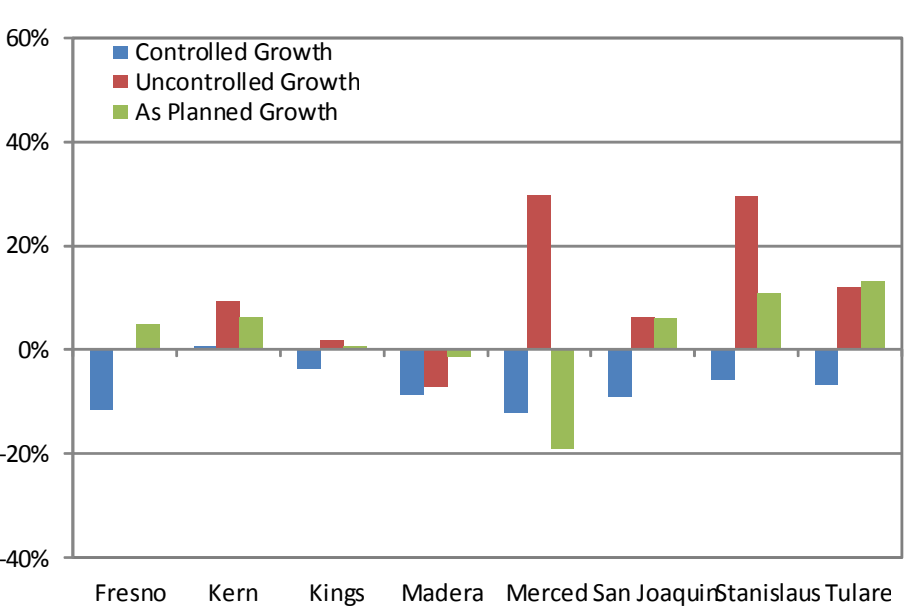

(b) $\mathrm{CO}$ emissions

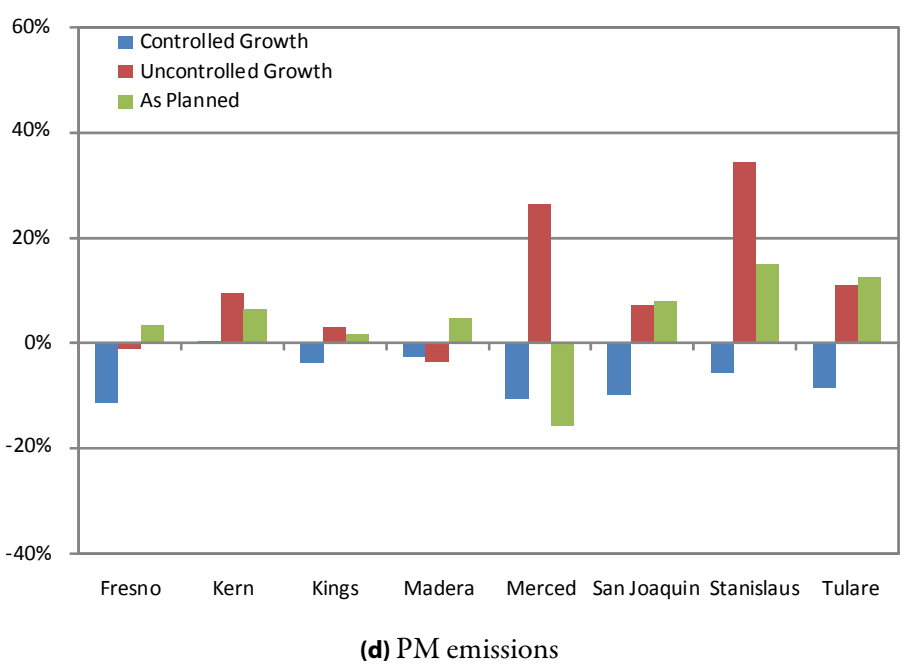

Figure 7: County-level mobile source emissions changes by 2030 vs. BG scenario.

tiveness of locating near transit stations). In other words, the distribution of new population does not affect the projected distribution of new commercial and industrial development, and jobs/housing balance was not a consideration in the development of the scenarios. Taking into account the local scale factors and a better job/population balance in the land use and built environment strategies might result in further improvements. Finally, while we have not specifically incorporated estimates of uncertainty in the modeling process, and these effects will certainly play a role in the accuracy of future forecasts, the range of elasticities across the counties gives some indication of the overall uncertainty, or at least the dependence of the elasticity on other factors. ${ }^{2}$

\footnotetext{
${ }^{2}$ For additional information on the effect of uncertainty in travel models, see Pradhan and Kockelman (2002).
}

Coordinating land use strategies with transportation and air quality improvement is particularly challenging in areas such as the SJV region, where rapid growth is occurring and future development is expected. The comparison and elasticity values developed in this study suggest that compact growth may be better than urban sprawl in terms of reducing vehicle activities and costs for the environment. This work also has implications for greenhouse gas (GHG) reductions: as VMT decreases so will GHG emissions. However, compact growth with high residential density is not only hard to achieve, it also likely insufficient to fully accommodate travel demand without air quality impacts in a rapidly growing region. Our conclusion points not so much to the futility of this approach as to the necessity of adopting a package of complementary policies (such as pricing and technological improvements) in order to achieve the needed reductions in vehicle emissions. 
Table 9: Vehicle emissions results and elasticity by county: CG vs. AP scenarios.

\begin{tabular}{|c|c|c|c|c|c|c|c|c|}
\hline \multirow[t]{2}{*}{ County } & \multicolumn{4}{|c|}{ \% Change in emissions (CG vs. AP) } & \multicolumn{4}{|c|}{ Elasticity (emissions vs. density) } \\
\hline & TOG & $\mathrm{CO}$ & $\mathrm{NO}_{x}$ & PM & TOG & $\mathrm{CO}$ & $\mathrm{NO}_{x}$ & PM \\
\hline Kern & 0 & -5 & -5 & -6 & 0 & -0.04 & -0.05 & -0.05 \\
\hline Kings & -1 & -4 & -4 & -5 & -0.01 & -0.03 & -0.04 & -0.04 \\
\hline Madera & -6 & -7 & -8 & -7 & -0.04 & -0.05 & -0.05 & -0.05 \\
\hline Merced & +11 & +8 & +8 & +6 & +0.10 & +0.07 & +0.07 & +0.05 \\
\hline San Joaquin & -17 & -14 & -15 & -17 & -0.19 & -0.16 & -0.17 & -0.19 \\
\hline Stanislaus & -13 & -15 & -16 & -18 & -0.12 & -0.14 & -0.15 & -0.17 \\
\hline Tulare & -13 & -18 & -18 & -19 & -0.10 & -0.14 & -0.14 & -0.14 \\
\hline
\end{tabular}

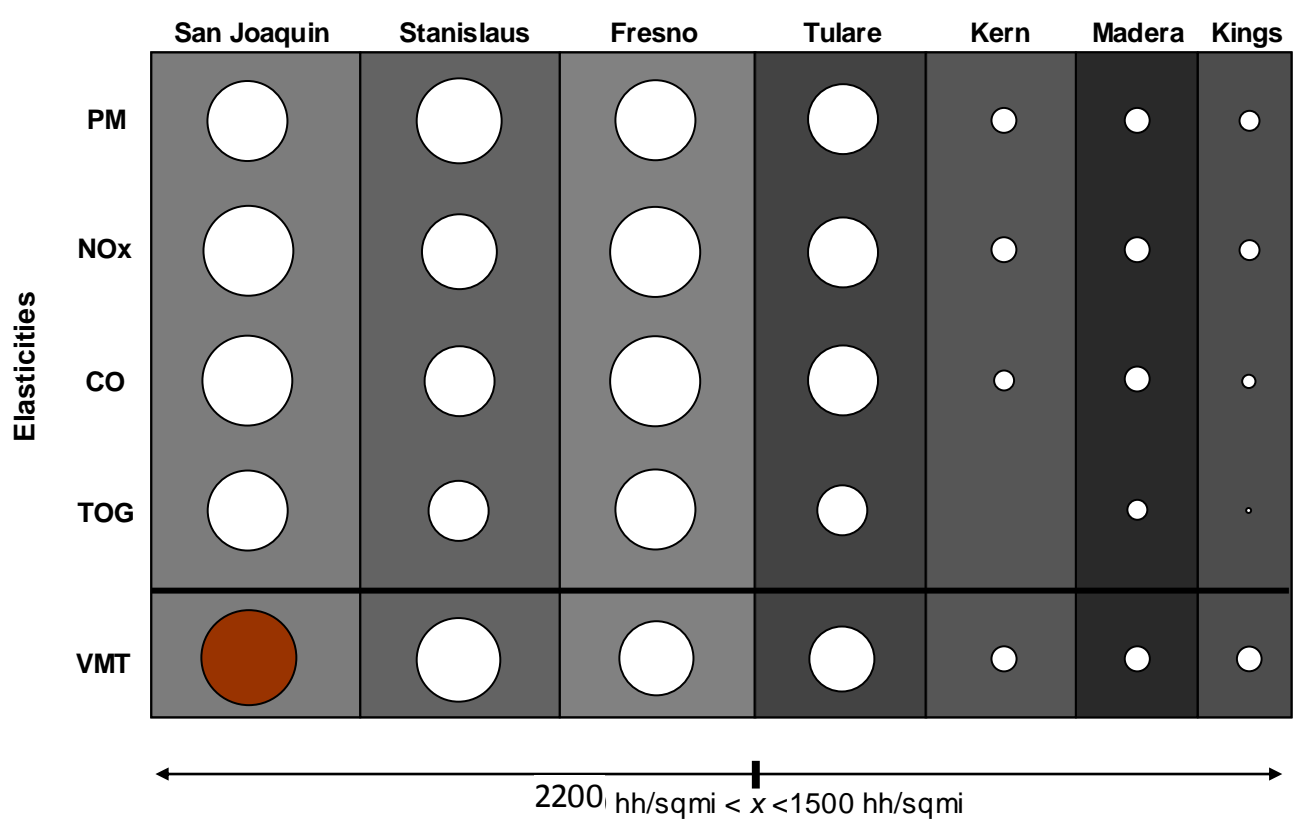

Figure 8: Elasticity comparisons. In this figure the circles (elasticities) scale to the San Joaquin VMT elasticity. The size of the boxes represent year 2000 densities (hh/sq. mi.) and grey color scale represents the change in densities from the As Planned to Compact Growth scenarios (darker indicates greater change from year 2000 densities). 


\section{Acknowledgements}

This research was partially funded by the United States Environmental Protection Agency under grant RD-83184201 and NSF grant BES-0302538. The authors would like to thank the expert panel members (Marla Mueller, California Energy Commission; Dan Leavitt, California High Speed Rail Authority; Karen Magliano, California Air Resources Board; Mike Brady, California Department of Transportation; Carolyn Lott, the Great Valley Center; Adrian Fleissig, Professor of Economics, California State University, Fullerton; and Frank Mitloehner, agricultural policy expert, University of California at Davis) for their valuable comments on policy scenario constructions. The authors also would like to thank Shengyi Gao, Sangho Choo, and Julie Ogilvie (UC Davis), and Bryan Penfold (Sonoma Technology, Inc.) for their technical assistance at the early stage of this research. In addition, we note that Song Bai is now employed with Sonoma Technology, Inc., Petaluma, CA USA.

\section{References}

Badoe, D. and E. Miller. 2000. Transportation-land-use interaction: Empirical findings in North America, and their implications for modeling. Transportation Research Part D, 5(4):235-263. doi: 10.1016/S1361-9209(99)00036-X.

Bartholomew, K. 2007. Land use-transportation scenario planning: Promise and reality. Transportation, 34(4):397-412. doi: 10.1007/s11116-006-9108-2.

California Department of Finance. 2007. Population projections for California and its counties 2000-2050, by age, gender and race/ethnicity. Technical report, California Department of Finance, Sacramento, California. URL http://www.dof.ca.gov/research/demographic/ reports/projections/p-3/.

California High-Speed Rail Authority. 2000. Building a High-Speed Train System for California: Final Business Plan. California High-Speed Rail Authority. URL http://trid. trb.org/view.aspx?id=844320.

Cervero, R. 1996. Mixed land-uses and commuting: Evidence from the American Housing Survey. Transportation Research A, 30(5):361-377. doi: 10.1016/09658564(95)00033-X.

Cervero, R. and K. M. Kockelman. 1997. Travel demand and the 3 Ds: Density, diversity, and design. Transportation Research Part D: Transport and Environment, 2(3):199-219. doi: 10.1016/S1361-9209(97)00009-6.
Dunphy, R. and K. Fisher. 1996. Transportation, congestion, and density: New insights. Transportation Research Record, 1552:89-96. doi: 10.3141/1552-12.

Ewing, R., K. Bartholomew, S. Winkelman, J. Walters, and D. Chen. 2007. Growing Cooler: The Evidence on Urban Development and Climate Change. Urban Land Institute. URL http://trid.trb.org/view.aspx?type $=$ MO\&id $=844311$.

Ewing, R. and R. Cervero. 2001. Travel and the built environment: A synthesis. Transportation Research Record, 1780:87-114. doi: 10.3141/1780-10.

Ewing, R., R. Pendall, and D. Chen. 2002. Measuring sprawl and its impact. Technical report, Smart Growth America and U.S. Environmental Protection Agency, Washington, DC. URL http://www.smartgrowthamerica.org/ research/measuring-sprawl-and-its-impact/.

Frank, L., B. Stone, and W. Bachman. 2000. Linking land use with household vehicle emissions in the central Puget Sound: Methodological framework and findings. Transportation Research Part D: Transport and Environment, 5(3):173-196. doi: 10.1016/S1361-9209(99)00032-2.

Golob, T. and D. Brownstone. 2005. The impact of residential density on vehicle usage and energy consumption. Working Paper UCI-ITS-WP-05-1, University of California, Irvine, Institute of Transportation Studies. URL http://www.its.uci.edu/its/publications/papers/ ITS/UCI-ITS-WP-05-1.pdf.

Hall, J., V. Brajer, and F. Lurmann. 2006. The health and related economic benefits of attaining healthful air in the San Joaquin Valley. Technical report, California State University at Fullerton, Institute for Economic and Environmental Studies. URL http://business.fullerton.edu/centers/ iees/reports/SJVFinalReport.pdf.

Handy, S. 1996. Methodologies for exploring the link between urban form and travel behavior. Transportation Research Part D: Transport and Environment, 1(2):151-165. doi: 10.1016/S1361-9209(96)00010-7.

Johnston, R., D. Shabazian, and S. Gao. 2003. UPlan: a versatile urban growth model for transportation planning. Transportation Research Record, 1831:202-209. doi: 10.3141/1831-23.

Kockelman, K. 1997. Travel behavior as a function of accessibility, land use mixing, and land use balance: Evidence from the San Francisco Bay area. Transportation Research Record, 1607:116-125. doi: 10.3141/1607-16.

Liu, F. 2003. Quantifying travel and air-quality benefits of smart growth in Maryland's state implementation plan. Transportation Research Record, 1858:80-88. doi: 10.3141/1858-12. 
Louis Berger Group. 2004. Emissions benefits of land use planning strategies. Final Project Report FHWA TOPR 29, Federal Highway Administration and US Department of Transportation. URL http://www.fhwa.dot.gov/environment/air_quality/ conformity/research/benefits.pdf.

Miller, E. and A. Ibrahim. 1998. Urban form and vehicular travel: Some empirical findings. Transportation Research Record, 1617:18-27. doi: 10.3141/1617-03.

Niemeier, D. and Y. Zheng. 2004. Impact of finer grid resolution on the spatial distribution of vehicle emissions inventories. Environmental Science and Technology, 38(7):2133-2141. doi: 10.1021/es026398b.

Niemeier, D., Y. Zheng, and T. Kear. 2004. UCDrive: a new gridded mobile source emission inventory model. Atmospheric Environment, 38(2):305-319.

Pickrell, D. 1999. Transportation and land use. In J. GomezIbanez, W. Tye, and C. Winston, eds., Essays in Transportation Economics and Policy. Washington, DC: Brookings Institution Press.

Pradhan, A. and K. Kockelman. 2002. Uncertainty propagation in an integrated land use-transportation modeling framework: Output variation via UrbanSim. Transportation Research Record: Journal of the Transportation Research Board, 1805:128-135.

Stone, B. J., A. Mednick, T. Holloway, and S. Spak. 2007. Is compact growth good for air quality? Journal of the American Planning Association, 73(4):404-418. doi: 10.1080/01944360708978521.

U.S. Environmental Protection Agency. 2004. San Joaquin Valley ozone. URL http://www.epa.gov/region09/air/ sjvalley/. 